\title{
Pemurnian Emas dari Bijih Emas Berkadar Rendah Menggunakan Karbon Aktif dari Arang Tempurung Kelapa
}

\author{
Ani Mulyasuryani*) Bambang Ismuyanto dan Danar Purwonugroho \\ Jurusan Kimia, Fakultas Matematika dan Ilmu Pengetahuan Alam, Universitas Brawijaya, Jawa Timur 65145
}

Diterima 23-06-2010Ｄisetujui 23-05-2011

\begin{abstract}
The activated carbon from the coconut shell can be used as an adsorbent for the recovery of gold. The optimum condition for gold recovery was obtained at $\mathrm{pH} 3$ (for adsorption) and $\mathrm{pH} 5$ (for desorption) with $1 \mathrm{M}$ thyocyanate solution and a $5 \mathrm{~cm}$ length of column (the mass of activated carbon is 20 grams). In this condition, the average gold recovery is $90.00 \%$, silver $7.28 \%$ and copper $4.93 \%$, that were used several gold ore samples. The average purity degree of gold is $49.67 \%$, depend on the concentration of gold, silver and copper in the gold ore sample.
\end{abstract}

Keywords: activated carbon, coconut shell, gold ores, gold recovery

\section{PENDAHULUAN}

Bijih emas mengandung perak (10-15\%), sedikit tembaga dan besi serta logam $\mathrm{Bi}, \mathrm{Pb}, \mathrm{Sn}, \mathrm{Zn}$ dan platinum dalam jumlah mikro. Dalam bijih emas mensona, kandungan emas sekitar 1,20 gram per ton bijih, tembaga sekitar 0,99\%/ton bijih dan perak 2,32 gram per ton bijih (Adam 2005). Di alam, emas sering dijumpai, baik dalam keadaan bebas maupun dalam bentuk senyawanya, misalnya calaverite $\left(\mathrm{AuTe}_{2}\right)$, sylvanite $\left(\mathrm{AuAgTe}_{2}\right)$ dan petzite [(AuAg) $\left.{ }_{2} \mathrm{Te}\right]$ (Marsden \& House 2006). Proses pelarutan emas biasanya menggunakan sianida sebagai ligan menghasilkan ion kompleks $\left[\mathrm{Au}(\mathrm{CN})_{2}\right]^{-}\left(\mathrm{K}_{\mathrm{st}}=2 \times 10^{38}\right)$. Pada proses tersebut, tidak hanya emas yang larut sebagai sianida tetapi juga tembaga dan perak yang terdapat dalam bijih emas membentuk ion kompleks $\left[\mathrm{Cu}(\mathrm{CN})_{2}\right]^{-}\left(\mathrm{K}_{\mathrm{st}}=10^{24}\right)$; $\left[\mathrm{Cu}(\mathrm{CN})_{3}\right]^{=}\left(\mathrm{K}_{\mathrm{st}}=3,98 \times 10^{28}\right) ;\left[\mathrm{Cu}(\mathrm{CN})_{4}\right]^{3-}\left(\mathrm{K}_{\mathrm{st}}=1,99 \times 10^{30}\right)$ dan $\left[\mathrm{Ag}(\mathrm{CN})_{2}\right]\left(\mathrm{K}_{\mathrm{st}}=1,26 \times 10^{21}\right) ;\left[\mathrm{Ag}(\mathrm{CN})_{3}\right]=\left(\mathrm{K}_{\mathrm{st}}=6,31 \times 10^{21}\right)$; $\left[\mathrm{Ag}(\mathrm{CN})_{4}\right]^{3-}\left(\mathrm{K}_{\mathrm{st}}=5,01 \times 10^{20}\right)$ (Jiang et al. 2001; Klein \& Hurbult 1985). Oleh karena itu, perlu dilakukan pemisahan ion kompleks $\left[\mathrm{Au}(\mathrm{CN})_{2}\right]^{-}$dari ion logam sianida lain sehingga diperoleh emas murni.

Pemisahan ion kompleks $\left[\mathrm{Au}(\mathrm{CN})_{2}\right]^{-}$dapat dilakukan dengan menggunakan resin penukar anion yang dielusi dengan $\mathrm{NaOH}$. Sementara ini resin merupakan bahan sintetik yang cukup mahal, sehingga perlu dicari bahan alternatif sebagai adsorben. Karbon aktif telah dikembangkan sebagai adsorben pada recovery $\left[\mathrm{Au}(\mathrm{CN})_{2}\right]^{-}$(Suzuki et al. 1991). Salah satu sumber karbon aktif adalah arang tempurung kelapa.

\footnotetext{
*Telp: +628179603028

Email: mulyasuryani@yahoo.com
}

Karbon aktif merupakan adsorben yang bersifat non polar, sehingga lebih mudah mengadsorpsi molekul yang bersifat non polar. Oleh karena itu emas hasil pelindihan yaitu, $\left[\mathrm{Au}(\mathrm{CN})_{2}\right]^{-}$, yang bersifat polar, terlebih dahulu direaksikan dengan $\left[\left(\mathrm{C}_{16} \mathrm{H}_{33}\left(\mathrm{CH}_{3}\right)_{3} \mathrm{~N}\right)^{+} \cdot \mathrm{Br}\right.$, menghasilkan $\left[\left(\mathrm{C}_{16} \mathrm{H}_{33}\left(\mathrm{CH}_{3}\right)_{3} \mathrm{~N}\right)^{+}\right.$. $\left[\mathrm{Au}(\mathrm{CN})_{2}\right]^{-}$yang bersifat non polar. Reaksi pembentukan molekul $\left[\left(\mathrm{C}_{16} \mathrm{H}_{33}\left(\mathrm{CH}_{3}\right)_{3} \mathrm{~N}\right)^{+}\right.$. $\left[\mathrm{Au}(\mathrm{CN})_{2}\right]^{-}$ dipengaruhi oleh $\mathrm{pH}$ larutan, sehingga untuk mendesorpsi $\left[\mathrm{Au}(\mathrm{CN})_{2}\right]^{-}$kembali dapat dilakukan dengan mengatur $\mathrm{pH}$ desorpsi (Navarroa et al. 2006). Pada proses desorpsi dilakukan penggantian $\left[\mathrm{Au}(\mathrm{CN})_{2}\right]^{-}$oleh $\mathrm{SCN}^{-}$. Jumlah $\left[\mathrm{Au}(\mathrm{CN})_{2}\right]^{-}$yang dapat digantikan tergantung pada jumlah $\mathrm{SCN}$.

Pada penelitian ini telah dilakukan optimasi pemisahan emas (I) sianida dari perak (I) dan tembaga (I) sianida yang meliputi pengaturan $\mathrm{pH}$, pengaturan konsentrasi $\mathrm{SCN}^{-}$, dan panjang kolom adsorpsi. Dari hasil penelitian diketahui bahwa karbon aktif dari tempurung kelapa dapat digunakan sebagai adsorben pada pemurnian emas.

Kondisi optimum pemurnian emas dengan menggunakan sampel emas murni diperoleh pada $\mathrm{pH}$ adsorpsi 3, pH desorpsi 5, konsentrasi eluen ( $\left.\mathrm{SCN}^{-}\right) 1 \mathrm{M}$ dan panjang kolom $5 \mathrm{~cm}$ dengan berat karbon aktif 20 gram. Pada kondisi tersebut diperoleh recovery rata-rata emas sebesar $90,00 \%$, perak $7,28 \%$ dan tembaga $4,93 \%$, dengan menggunakan berbagai sampel bijih emas. Tingkat kemurnian emas maksimum mencapai $49,67 \%$, tergantung pada konsentrasi emas, perak dan tembaga yang terkandung dalam sampel bijih emas. 


\section{BAHANDANMETODE}

Bahan-bahan kimia yang digunakan dalam penelitian ini dengan derajat pro analis kecuali yang disebut khusus: larutan baku Au; Ag dan Cu masing-masing 1000 ppm, yang merupakan hasil pelarutan logam $\mathrm{Au}, \mathrm{Ag}$ dan $\mathrm{Cu}$ standar, sampel bijih emas, cetyltrimethyl ammoniumbromide (CTAB), kalium sianida ( $\mathrm{KCN})$, kalium tiosianat ( $\mathrm{KSCN}$ ), asam asetat, asam borat, asam fosfat, ammonium hidroksida $\left(\mathrm{NH}_{4} \mathrm{OH}\right) 25 \%(\mathrm{bj}=0,88 \mathrm{~g} / \mathrm{ml})$, karbon aktif granule, akuades.

Alat - alat yang digunakan dalam penelitian ini adalah neraca analitik merek Mettler AE166; bola hisap; seperangkat alat SSA merk Shimadzu AA 6200; pH meter merek Scott Gerat CG-820; kolom adsorpsi; pompa vakum; aerator; pengaduk magnet; serta peralatan gelas.

Pemisahan dilakukan dengan menggunakan kolom gelas dengan diameter $2,5 \mathrm{~cm}$ yang berisi karbon aktif dengan tinggi $5 \mathrm{~cm}$. Untuk mengatur kecepatan alir eluen pada saat adsorpsi dan desorpsi digunakan pompa vakum. Pelarutan bijih emas, dilakukan dengan menambahkan larutan kalium sianida 0,5 M ke dalam serbuk bijih emas. Oksidasi dilakukan dengan mengalirkan udara menggunakan aerator (Heinen et al. 1978). Penentuan kadar emas, perak dan tembaga digunakan spektrofotometer serapan atom.

Adsorpsi pada saat optimasi menggunakan larutan bijih emas, sebanyak 11 (20 gram dalam 11 larutan sianida). Ke dalam larutan tersebut telah ditambahkan CTAB 0,5 mM. Adsorpsi dilakukan pada $\mathrm{pH}$ antara 3 hingga 7, desorpsi dilakukan pada $\mathrm{pH}$ antara 5 hingga 10. Larutan untuk desorpsi digunakan larutan $\mathrm{SCN}^{-}$dalam buffer dengan $\mathrm{pH}$ bervariasi antara 5 hingga 9 sebanyak $20 \mathrm{ml}$. Konsentrasi $\mathrm{SCN}^{-}$yang digunakan $1 \mathrm{M}$. Kecepatan alir desorpsi ratarata berkisar antara antara $1-1,5 \mathrm{ml} /$ menit.

\section{HASIL DAN PEMBAHASAN}

Penentuan konsentrasi SCN- optimum. Pengaturan konsentrasi $\mathrm{SCN}^{-}$yang digunakan untuk desorpsi emas yang telah teradsorpsi di permukaan karbon aktif, bertujuan untuk meningkatkan efisiensi pemekatan konsentrasi emas. Dalam proses tersebut molekul $\left[\left(\mathrm{C}_{16} \mathrm{H}_{33}\left(\mathrm{CH}_{3}\right)_{3} \mathrm{~N}\right)^{+}\right.$. $\left[\mathrm{Au}(\mathrm{CN})_{2}\right]^{-}$yang telah terkonsentrasi dalam karbon aktif akan diganggu oleh adanya $\mathrm{SCN}^{-}$pada $\mathrm{pH}$ yang berbeda dengan $\mathrm{pH}$ adsorpsi. Ion $\left[\mathrm{Au}(\mathrm{CN})_{2}\right]^{-}$akan tergantikan oleh $\mathrm{SCN}^{-}$, menjadi $\left[\left(\mathrm{C}_{16} \mathrm{H}_{33}\left(\mathrm{CH}_{3}\right)_{3} \mathrm{~N}\right)^{+}\right.$. [SCN]- yang teradsorpsi dalam karbon aktif. Terjadinya pergantian tersebut, sangat dimungkinkan, karena keektronegatifan SCN- lebih besar dari $\left[\mathrm{Au}(\mathrm{CN})_{2}\right]^{-}$. Seperti halnya pada optimasi $\mathrm{pH}$ desorpsi, pada tahapan ini juga dilakukan dua tahap yaitu fraksinasi dan pengujian recovery. Pada tahap fraksinasi, hasil pengukuran absorbansi emas secara SSA, dapat dilihat pada Gambar 1. Berdasarkan Gambar 1 dapat diketahui bahwa semakin tinggi konsentrasi $\mathrm{SCN}^{-}$yang digunakan dapat meningkatkan nilai absorbansi yang dihasilkan. Hal ini menunjukkan bahwa jumlah emas yang terdesorpsi dipengaruhi oleh konsentrasi $\mathrm{SCN}^{-}$. Peningkatan konsentrasi $\mathrm{SCN}^{-}$tidak dapat dilakukan melebihi $1 \mathrm{M}$, karena dapat menimbulkan peningkatan kekuatan ion larutan yang terlalu besar. Kekuatan ion larutan yang terlalu tingi dapat menyebabkan terjadinya peningkatan penguraian ion $\left[\mathrm{Au}(\mathrm{CN})_{2}\right]^{-}$sehingga dapat mengganggu kesetimbangan adsorpsi-desorpsi.

Dari Gambar 1 diketahui bahwa pada konsentrasi SCNsebesar $1 \mathrm{M}$, nilai absorbansi sangat tinggi. Pada fraksi $15 \mathrm{ml}$, absorbansi emas mendekati nol, yang artinya sudah tidak ada emas yang dapat didesorpsi. sedangkan pada konsentrasi $\mathrm{SCN}^{-} 0,1$ dan 0,5 $\mathrm{M}$, terjadi tailing. Hal ini menunjukkan bahwa jumlah $\mathrm{SCN}^{-}$pada kedua konsentrasi tersebut mempunyai kemampuan yang kurang maksimum untuk menggantikan $\left[\mathrm{Au}(\mathrm{CN})_{2}\right]^{-}$. Oleh karena itu pada tahap selanjutnya, dilakukan pengujian recovery pada $15 \mathrm{ml}$ untuk setiap konsentrasi $\mathrm{SCN}^{-}$yang digunakan.

Berdasarkan hasil fraksinasi dilakukan uji recovery (\%), untuk setiap SCN` pada $15 \mathrm{ml}$ eluat pertama. Data recovery emas pada berbagai konsentrasi $\mathrm{SCN}^{-}$ditampilkan pada Tabel 1. Berdasarkan data elusi dan data recovery dapat diketahui bahwa adanya peningkatan recovery emas dengan bertambahnya konsentrasi $\mathrm{SCN}^{-}$. Recovery emas yang dihasilkan sebesar 47,63\%, dengan menggunakan larutan $\mathrm{SCN}^{-} 1 \mathrm{M}$ pada saat desorpsi. Akan tetapi recovery emas yang dihasilkan masih kurang dari 50\%. Hal ini mungkin disebabkan oleh kemampuan karbon aktif untuk mengadsorpsi molekul $\left[\left(\mathrm{C}_{16} \mathrm{H}_{33}\left(\mathrm{CH}_{3}\right)_{3} \mathrm{~N}\right)^{+} \text {. } \mathrm{Au}(\mathrm{CN})_{2}\right]^{-}$tidak sebanding dengan jumlah molekul tersebut. Pada kondisi

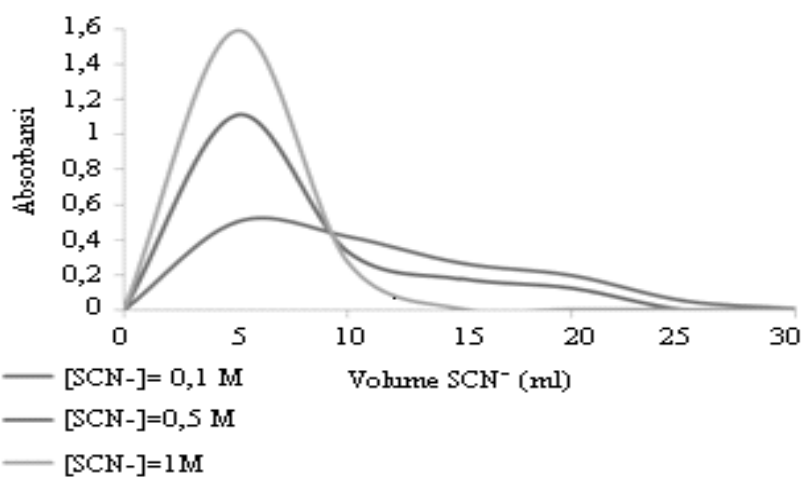

Gambar 1 Kurva hubungan volume $\mathrm{SCN}^{-}(\mathrm{ml})$ terhadap absorbansi emas hasil desorpsi yang diukur secara SSA, pada berbagai konsentrasi $\mathrm{SCN}^{-}$ 
ini digunakan jumlah karbon aktif sebanyak 6 gram (tinggi kolom $2 \mathrm{~cm}$ ). Untuk meningkatkan recovery emas yang lebih besar dilakukan pengaturan jumlah karbon aktif yang digunakan.

Penentuan panjang kolom optimum. Berdasarkan hasil uji recovery emas, perak dan tembaga pada kondisi optimum emas, perlu dilakukan pengaturan kembali kondisi pemurnian emas dari sampel bijih emas. Konsentrasi $\mathrm{SCN}^{-}$dan $\mathrm{pH}$ merupakan faktor yang mempengaruhi kestabilan kompleks sianida. Pada kondisi pH optimum untuk emas, diasumsikan bahwa kompleks sianida yang paling stabil adalah $\left[\mathrm{Au}(\mathrm{CN})_{2}\right]^{-}$. Oleh karena itu, pengaturan yang perlu dilakukan adalah panjang kolom. Dilakukan kembali adsorpsi larutan sampel, dan fraksinasi pada panjang kolom $2,5 \mathrm{~cm} ; 5 \mathrm{~cm}$ dan 7,5 cm. Pengukuran absorbansi secara SSA dilakukan pada setiap $10 \mathrm{ml}$ eluat yang keluar dari kolom. Berdasarkan harga absorbansi dari emas, perak dan tembaga, dengan menggunakan kurva baku, dapat dihitung recovery dari ketiga logam tersebut.

Hasil penelitian menunjukkan bahwa pada panjang kolom 2,5 cm, jumlah tembaga yang diadsorpsi hanya mencapai $48 \%$, sedangkan pada panjang kolom $5 \mathrm{~cm}$, jumlah perak yang diadsorpsi kurang dari 50\%. Fenomena tersebut menunjukkan bahwa pada $\mathrm{pH}=4$, yang paling banyak diadsorpsi adalah $\left[\left(\mathrm{C}_{16} \mathrm{H}_{33}\left(\mathrm{CH}_{3}\right)_{3} \mathrm{~N}\right)^{+} \text {. [ } \mathrm{Au}(\mathrm{CN})_{2}\right]^{-}$. Pada panjang kolom $7,5 \mathrm{~cm}$, jumlah karbon aktif cukup memadai untuk mengadsorpsi semua molekul yang ada, sehingga baik perak maupun tembaga diadsorpsi dengan baik. Recovery emas, perak dan tembaga pada $20 \mathrm{ml}$ eluat pertama, tercantum dalam Tabel 2.

Dari Tabel 2 dapat dilihat bahwa pada panjang kolom $2,5 \mathrm{~cm}$, recovery emas mencapai 52,90\%, akan tetapi masih terdapat perak dan tembaga. Hasil pemurnian mengandung $62 \%$ emas; $16 \%$ perak dan $22 \%$ tembaga. Dengan menggunakan panjang kolom $5 \mathrm{~cm}$ diperoleh $84 \%$ emas; $12 \%$ perak dan $3 \%$ tembaga, sedangkan pada panjang kolom $7,5 \mathrm{~cm}$ dihasilkan $41 \%$ emas; $8 \%$ perak dan $51 \%$ tembaga.

Tabel 1 Data recovery emas (\%) pada berbagai konsentrasi SCN yang digunakan pada saat desorpsi

\begin{tabular}{ccccc}
\hline $\begin{array}{c}{\left[\mathrm{SCN}^{-}\right]} \\
(\mathrm{M})\end{array}$ & $\mathrm{A}$ & $\begin{array}{c}{[\mathrm{Au}]} \\
(\mathrm{ppm})\end{array}$ & $\begin{array}{c}\text { Massa Au } \\
(\mathrm{mg})\end{array}$ & $\begin{array}{c}\text { Recovery } \\
(\%)\end{array}$ \\
\hline 0,1 & 0,3922 & 19,51 & 0,29 & 29,27 \\
0,5 & 0,5268 & 26,21 & 0,39 & 39,31 \\
1,0 & 0,6383 & 31,76 & 0,48 & 47,63 \\
\hline
\end{tabular}

Tabel 2 Data recovery emas, perak dan tembaga dari sampel bijih emas pada berbagai panjang kolom

\begin{tabular}{cccc}
\hline \multirow{2}{*}{ Unsur } & \multicolumn{3}{c}{ Recovery $(\%)$} \\
\cline { 2 - 4 } & $1=2,5 \mathrm{~cm}$ & $1=5 \mathrm{~cm}$ & $\mathrm{~L}=7,5 \mathrm{~cm}$ \\
\hline $\mathrm{Au}$ & 52,90 & 46,31 & 21,08 \\
$\mathrm{Ag}$ & 13,57 & 6,82 & 4,12 \\
$\mathrm{Cu}$ & 18,72 & 1,84 & 26,51 \\
\hline
\end{tabular}

Berdasarkan data tersebut dapat disimpulkan bahwa kadar emas yang paling baik dihasilkan pada panjang kolom $5 \mathrm{~cm}$. Walaupun demikian, kemurnian emas masih lebih kecil dari 95\%, sehingga perlu dilakukan pengujian lebih lanjut dengan menggunakan sampel bijih emas yang lain.

Pengaturan pH adsorpsi optimum. Penentuan kondisi optimum $\mathrm{pH}$ adsorpsi dilakukan mengatur $\mathrm{pH}$ saat adsorpsi 11 larutan sampel bijih, kemudian dilakukan desorpsi pada pH 6, Sesuai hasil penelitian terdahulu. Desorpsi dilakukan dengan menggunakan $20 \mathrm{ml}$ larutan KSCN 1 M. Hasil recovery pada berbagai $\mathrm{pH}$ adsorpsi dapat dilihat pada Gambar 2.

Dari Gambar 2 dapat dilihat bahwa pada proses adsorpsi dengan $\mathrm{pH} 3$, emas dapat didesorpsi dengan baik pada $\mathrm{pH}$ 6. sedangkan perak dan tembaga tidak dapat didesorpsi. Hal ini mungkin terjadi karena pada $\mathrm{pH} 3$, emas, perak dan tembaga berada sebagai ion kompleks $\left[\mathrm{Au}(\mathrm{CN})_{2}\right]$; $\left[\mathrm{Ag}(\mathrm{CN})_{2}\right]^{-}$dan $\left[\mathrm{Cu}(\mathrm{CN})_{2}\right]^{-}$. Pada kondisi ini ion kompleks paling tidak stabil adalah $\left[\mathrm{Ag}(\mathrm{CN})_{2}\right]^{-}$, sehingga seharusnya yang paling mudah didesorpsi adalah $\left[\mathrm{Ag}(\mathrm{CN})_{2}\right]^{-}$. Namun pada $\mathrm{pH}$ yang sedikit netral $\left[\mathrm{Ag}(\mathrm{CN})_{2}\right]^{-}$, tanpa adanya $\mathrm{CN}^{-}$ bebas dalam larutan dapat berubah menjadi $\operatorname{Ag}_{2} \mathrm{O}$ atau $\mathrm{AgSCN}$ (dalam larutan yang mengandung $\mathrm{SCN}^{-}$) yang dapat mengendap pada permukaan karbon aktif. Hal tersebut yang menyebabkan recovery perak menjadi rendah. Fenomena yang sama terjadi pada $\left[\mathrm{Cu}(\mathrm{CN})_{2}\right]^{-}$, yang akan berubah menjadi $\mathrm{Cu}_{2} \mathrm{O}$ atau CuSCN (Marsden \& House 2006). Dengan demikian pada adsorpsi $\mathrm{pH} 3$, recovery yang paling besar adalah emas. Gejala yang sama terjadi pada adsorpsi $\mathrm{pH}$ 4. Terjadinya penurunan recovery emas pada $\mathrm{pH} 4$, kemungkinan disebabkan oleh adanya sebagian tembaga dalam bentuk ion kompleks $\left[\mathrm{Cu}(\mathrm{CN})_{3}\right]^{2-}$, sehingga pada saat desorpsi akan membentuk $\left[\mathrm{Cu}(\mathrm{CN})_{2}\right]$. Hal tersebut akan terjadi kompetisi antara pertukaran $\left[\mathrm{Au}(\mathrm{CN})_{2}\right]^{-}$dan $\left[\mathrm{Cu}(\mathrm{CN})_{2}\right]^{-}$ oleh $\mathrm{SCN}^{-}$, sehingga recovery emas sedikit menurun dan tembaga meningkat.

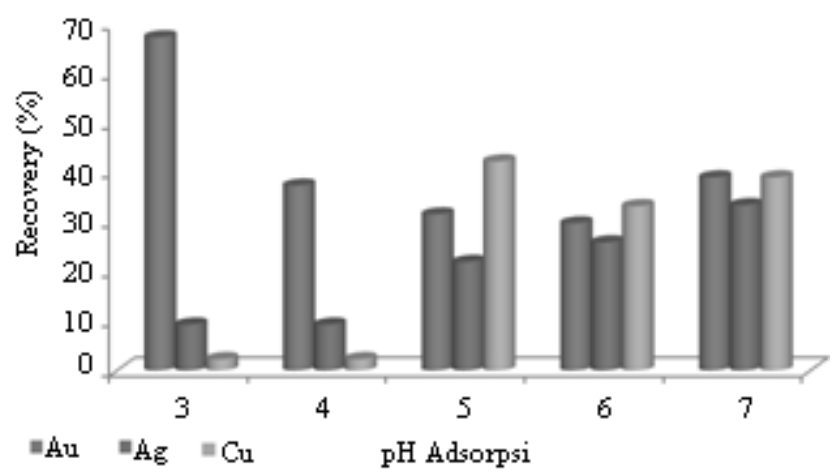

Gambar 2 Kurva pengaruh $\mathrm{pH}$ adsorpsi terhadap recovery emas, perak dan tembaga 
Pada proses adsorpsi dengan $\mathrm{pH}$ 5, ion kompleks perak dan tembaga merupakan campuran dari $\left[\mathrm{Ag}(\mathrm{CN})_{2}\right]^{-}$dan $\left[\mathrm{Ag}(\mathrm{CN})_{3}\right]^{2-}$ serta $\left[\mathrm{Cu}(\mathrm{CN})_{2}\right]^{-}$dan $\left[\mathrm{Cu}(\mathrm{CN})_{3}\right]^{2-}$, diperkirakan ion kompleks $\left[\mathrm{Cu}(\mathrm{CN})_{3}\right]^{2-}$ lebih banyak daripada $\left[\mathrm{Cu}(\mathrm{CN})_{2}\right]^{-}$, sehingga recovery tembaga lebih besar, dan sebaliknya untuk perak. Emas pada pH 5 tetap sebagai $\left[\mathrm{Au}(\mathrm{CN})_{2}\right]^{-}$dan lebih stabil dari pada $\left[\mathrm{Cu}(\mathrm{CN})_{2}\right]^{-}$, sehingga recovery emas lebih kecil daripada tembaga. Gejala yang hampir sama terjadi pada adsorpsi dengan $\mathrm{pH}$ 6, akan tetapi jumlah $\left[\mathrm{Ag}(\mathrm{CN})_{3}\right]^{2-}$ lebih banyak daripada $\left[\mathrm{Ag}(\mathrm{CN})_{2}\right]^{-}$, sehingga recovery perak meningkat, lebih besar daripada recovery emas.

Pada adsorpsi $\mathrm{pH}$ 7, kemungkinan tembaga terdapat sebagai $\left[\mathrm{Cu}(\mathrm{CN})_{2}\right]^{-} ;\left[\mathrm{Cu}(\mathrm{CN})_{3}\right]^{2}$ dan $\left[\mathrm{Cu}(\mathrm{CN})_{4}\right]^{3-}$, yang dapat terdesorpsi sebagai $\left[\mathrm{Cu}(\mathrm{CN})_{2}\right]^{-}$dan $\left[\mathrm{Cu}(\mathrm{CN})_{3}\right]^{2}$, sehingga seolah-olah mempunyai dua puncak. Pada kondisi ini $\left[\mathrm{Au}(\mathrm{CN})_{2}\right]^{-}$akan semakin stabil sehingga sulit untuk didesorpsi yang mengakibatkan terjadinya tailing. Jumlah $\left[\mathrm{Ag}(\mathrm{CN})_{3}\right]^{2-}$ akan jauh lebih banyak daripada $\left[\mathrm{Ag}(\mathrm{CN})_{2}\right]^{-}$ sehingga pada saat desorpsi berubah menjadi $\left[\mathrm{Ag}(\mathrm{CN})_{2}\right]^{-}$.

Dari uraian di atas dapat disimpulkan bahwa $\mathrm{pH}$ adsorpsi optimum recovery emas adalah pada $\mathrm{pH} 3$. Pada kondisi tersebut recovery emas sebesar $67,34 \%$, perak $9,26 \%$ dan tembaga 2,29\%. Peningkatan $\mathrm{pH}$ dari 3 hingga 7 menurunkan recovery emas yaitu berkisar antara 29-39\%. Adanya peningkatan $\mathrm{pH}$ adsorpsi dapat meningkatkan recovery perak dan tembaga. Hal ini dapat terjadi karena $\mathrm{pH}$ berpengaruh terhadap pembentukan kompleks sianida. Peningkatan $\mathrm{pH}$ larutan dapat mendorong terbentuknya ion kompleks sianida dan sebaliknya pada $\mathrm{pH}$ rendah kompleks sianida cenderung mengurai. Adanya perbedaan jumlah muatan ion kompleks dimungkinkan dapat mempengaruhi proses desorpsi sehingga dapat mempengaruhi harga recovery.

Penentuan pH desorpsi optimum. Pengaturan $\mathrm{pH}$ yang digunakan untuk desorpsi emas yang telah teradsorpsi di permukaan karbon aktif, bertujuan untuk meningkatkan recovery emas. Dalam proses tersebut molekul $\left[\left(\mathrm{C}_{16} \mathrm{H}_{33}\left(\mathrm{CH}_{3}\right)_{3} \mathrm{~N}\right)^{+} \text {. [ } \mathrm{Au}(\mathrm{CN})_{2}\right]^{-}$yang telah terkonsentrasi dalam karbon aktif akan diganggu oleh adanya SCN pada $\mathrm{pH}$ yang berbeda dengan $\mathrm{pH}$ adsorpsi. Ion $\left[\mathrm{Au}(\mathrm{CN})_{2}\right]^{-}$akan tergantikan oleh $\mathrm{SCN}^{-}$, menjadi $\left[\left(\mathrm{C}_{16} \mathrm{H}_{33}\left(\mathrm{CH}_{3}\right)_{3} \mathrm{~N}\right)^{+}\right.$. [SCN]', yang teradsorpsi dalam karbon aktif. Pergantian tersebut dapat terjadi jika kestabilan ion $\left[\mathrm{Au}(\mathrm{CN})_{2}\right]^{-}$menurun dengan adanya perubahan $\mathrm{pH}$ (Grosse et al. 2003).
Proses adsorpsi dilakukan pada $\mathrm{pH} 3$, pada kondisi ini ion-ion kompleks sianida dalam bentuk $\left[\mathrm{Au}(\mathrm{CN})_{2}\right]^{\text {; }}$; $\left[\mathrm{Ag}(\mathrm{CN})_{2}\right]^{-}$dan $\left[\mathrm{Cu}(\mathrm{CN})_{2}\right]^{-}$, yang kemudian direaksikan dengan CTAB. Molekul yang teradsorpsi pada permukaan karbon aktif adalah $\left[\left(\mathrm{C}_{16} \mathrm{H}_{33}\left(\mathrm{CH}_{3}\right)_{3} \mathrm{~N}\right)^{+}\right.$. $\left.\mathrm{Au}(\mathrm{CN})_{2}\right],\left[\left(\mathrm{C}_{16} \mathrm{H}_{33}\left(\mathrm{CH}_{3}\right)_{3} \mathrm{~N}\right)^{+} \text {. } \mathrm{Ag}(\mathrm{CN})_{2}\right]^{-} \mathrm{d}$ a n $\left[\left(\mathrm{C}_{16} \mathrm{H}_{33}\left(\mathrm{CH}_{3}\right)_{3} \mathrm{~N}\right)^{+}\right.$. $\left[\mathrm{Cu}(\mathrm{CN})_{2}\right]^{-}$. Ion kompleks yang akan lebih dahulu ditukar oleh $\mathrm{SCN}^{-}$adalah ion kompleks yang paling tidak stabil, dengan urutan kestabilan $\left[\mathrm{Ag}(\mathrm{CN})_{2}\right]$ $<\left[\mathrm{Cu}(\mathrm{CN})_{2}\right]^{-}<\left[\mathrm{Au}(\mathrm{CN})_{2}\right]^{-}$.

Seperti halnya pada optimasi $\mathrm{pH}$ adsorpsi, pada tahapan ini juga dilakukan desorpsi dengan $20 \mathrm{ml}$ larutan KSCN pada berbagai $\mathrm{pH}$. Hasil pengukuran secara SSA dikonversi menjadi recovery berdasarkan konsentrasi emas, perak dan tembaga dalam larutan sampel bijih emas. Dari Gambar 3, diketahui bahwa jumlah emas terbanyak yang dapat didesorpsi dihasilkan pada $\mathrm{pH}$ 5. Pada $\mathrm{pH}$ tersebut, recovery emas > perak > tembaga, hal ini terjadi karena kestabilan $\left[\mathrm{Ag}(\mathrm{CN})_{2}\right]^{-}$dan $\left[\mathrm{Cu}(\mathrm{CN})_{2}\right]^{-}$jauh lebih kecil daripada $\left[\mathrm{Au}(\mathrm{CN})_{2}\right]^{-}$, ion $\left[\mathrm{Ag}(\mathrm{CN})_{2}\right]^{-}$dan $\left[\mathrm{Cu}(\mathrm{CN})_{2}\right]^{-}$.

Hasil desorpsi dapat terurai pada $\mathrm{pH} 5$, membentuk $\mathrm{AgSCN}$ dan $\mathrm{CuSCN}$ dengan adanya larutan $\mathrm{SCN}^{-}$. Kelarutan $\operatorname{AgSCN}\left(\mathrm{K}_{\mathrm{sp}}=1,1 \times 10^{-12}\right)$ lebih besar daripada kelarutan $\operatorname{CuSCN}\left(\mathrm{K}_{\mathrm{sp}}=4 \times 10^{-14}\right)$, akan tetapi keduanya dapat mengendap pada permukaan karbon aktif, akibatnya recovery perak dan tembaga sangat kecil dan recovery perak sedikit lebih besar daripada tembaga. Gejala yang sama terjadi pada $\mathrm{pH} 6$, tetapi $\left[\mathrm{Au}(\mathrm{CN})_{2}\right]^{-}$lebih stabil, sehingga lebih sulit didesorpsi, maka recovery emas menurun.

Pada desorpsi pH 7 hingga 9, urutan ion kompleks yang didesorpsi berturut-turut adalah $\left[\mathrm{Ag}(\mathrm{CN})_{2}\right]^{-} ;\left[\mathrm{Cu}(\mathrm{CN})_{2}\right]^{-}$ dan $\left[\mathrm{Au}(\mathrm{CN})_{2}\right]^{-}$. akan tetapi pada media larutan yang tidak mengandung $\mathrm{CN}^{-}$kemungkinan $\left[\mathrm{Ag}(\mathrm{CN})_{2}\right]^{-}$dapat berubah menjadi $\mathrm{Ag}_{2} \mathrm{O}\left(\mathrm{K}_{\mathrm{sp}}=3,8 \times 10^{-16}\right)$ dan $\left[\mathrm{Cu}(\mathrm{CN})_{2}\right]^{-}$menjadi $\mathrm{Cu}_{2} \mathrm{O}$ $\left(\mathrm{K}_{\mathrm{sp}}=4 \times 10^{-30}\right)$ sehingga keduanya mempunyai recovery yang rendah. Sedangkan $\left[\mathrm{Au}(\mathrm{CN})_{2}\right]^{-}$akan semakin stabil pada $\mathrm{pH}$ yang semakin basa sehingga semakin sulit untuk

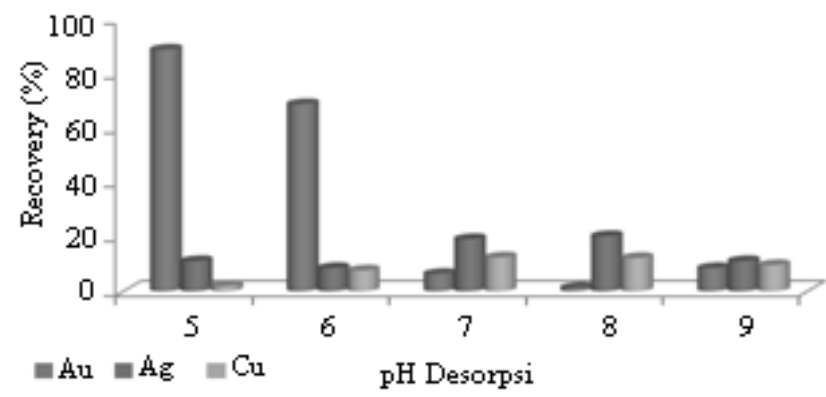

Gambar 3 Kurva pengaruh $\mathrm{pH}$ desorpsi terhadap recovery emas, perak dan tembaga 
didesorpsi. Berdasarkan hasil optimasi $\mathrm{pH}$ desorpsi dapat diketahui bahwa recovery emas terbesar dihasilkan pada desorpsi dengan $\mathrm{pH} 5$, pada kondisi tersebut recovery emas $88,87 \%$; perak $11,11 \%$ dan tembaga $2,02 \%$.

Pengujian recovery emas dari berbagai sampel bijih emas. Dari penentuan kondisi optimum diketahui bahwa recovery emas tertinggi dihasilkan pada adsorpsi $\mathrm{pH} 3$, desorpsi pH 5. Sampel bijih merupakan serbuk 100 mesh, dilarutkan dalam larutan 0,5 M KCN, pelarutan atau leaching memerlukan oksigen, dengan lama pelarutan 48 jam. Untuk mengetahui kadar emas dalam bijih, dilakukan pengukuran aborbansi emas secara SSA pada larutan sampel bijih emas. Selain itu, dalam bijih emas terkandung pula perak dan tembaga yang dapat terlarutkan dengan KCN kompleks perak (I) sianida dan tembaga (I) sianida, oleh karena itu perlu diukur kadar perak dan tembaga yang terdapat dalam sampel.

Berdasarkan Gambar 4, diketahui bahwa konsentrasi emas, perak dan tembaga hasil recovery lebih besar daripada konsentrasi sampel. Hal ini menunjukkan bahwa terjadi pemekatan konsentrasi dari ketiga logam tersebut. Adanya pemekatan konsentrasi mengindikasikan adanya akumulasi yang disebabkan oleh proses adsorpsi oleh karbon aktif. Pemekatan terjadi karena ion-ion kompleks logam yang teradsorpsi pada $\mathrm{pH} 3$, dapat mengurai pada $\mathrm{pH}$ 5, sehingga terjadi desorpsi. Desorpsi berlangsung cepat oleh karena itu dengan menggunakan $20 \mathrm{ml}$ larutan $\mathrm{SCN}^{-}$, ketiga ion tersebut dapat keluar dari kolom. Tingkat pemekatan konsentrasi emas rata-rata mencapai 45 kali, sedangkan untuk perak dan tembaga 3 dan 2 kali konsentrasi semula. Perbedaan tingkat pemekatan mungkin disebabkan oleh adanya perbedaan kestabilan kompleks antara ketiga ion kompleks sianida tersebut. Ion kompleks $\mathrm{Au}(\mathrm{CN})_{2}$ merupakan kompleks sianida yang paling stabil sedangkan $\mathrm{Ag}(\mathrm{CN})_{2}{ }^{-}$paling tidak stabil, akan tetapi konsentrasi perak dalam ketiga sampel bijih emas paling tinggi, sehingga tingkat pemekatan perak lebih besar daripada tembaga.

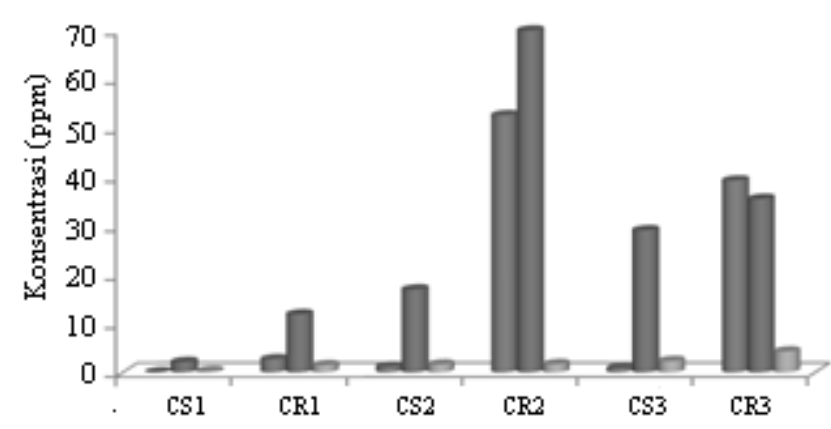

$\mathrm{Au}=\mathrm{Ag}=\mathrm{Cu}$

Gambar 4 Kurva konsentrasi emas, perak dan tembaga pada sampel (CS) dan hasil recovery (CR) pada berbagai jenis sampel
Persentase massa emas hasil recovery mengalami peningkatan dibandingkan persentase dalam sampel bijih emas. Untuk ketiga sampel bijih emas yang digunakan diketahui bahwa persentase yang paling tinggi dalam bijih emas adalah perak, sedangkan emas mempunyai persentase paling rendah. Hasil recovery persentase emas mengalami peningkatan yang cukup besar (Gambar 5). Pada sampel 1 (MS1) persentase emas dalam sampel sangat kecil, hanya $2 \%$. Setelah recovery meningkat menjadi $16 \%$, sedangkan persentase perak dan tembaga menurun. Pada sampel 2 dan 3 (MS2 dan MS3) persentase massa emas meningkat mendekati 50\% (MR2 dan MR3), sedangkan perak menurun cukup besar. Hal ini menunjukkan bahwa proses pemurnian sangat selektif terhadap emas.

Berdasarkan dari hasil pengujian dapat diketahui \% recovery rata-rata dari emas, perak dan tembaga masing 90,00; 7,28 dan 4,93\%. Dengan menggunakan sampel bijih emas berkadar rendah pada sampel 1, tingkat kemurnian emas meningkat dari 2,37\% menjadi 16,88\%. Apabila konsentrasi emas dalam sampel bijih meningkat maka tingkat kemurnian emas hasil pemisahan meningkat secara signifikan, hal ini terlihat pada sampel bijih 2 dan 3 yaitu dari 5,98 menjadi 42,34\% dan dari 2,6 menjadi 49,67\%. Tingkat kemurnian emas yang dihasilkan sangat bergantung pada konsentrasi logam-logam lain dalam hal ini perak dan tembaga, yang terkandung dalam sampel bijih emas.

Dengan demikian metoda pemurnian yang dikembangkan cukup selektif untuk pemurnian emas. Walaupun demikian, karena dalam sampel bijih emas kadar yang paling tinggi adalah perak, maka hasil pemisahan belum menghasilkan emas murni $100 \%$. Untuk mencapai tingkat kemurnian tersebut perlu dilakukan proses pemisahan berulang kali, sehingga dihasilkan persentase massa emas mendekati $100 \%$. Hal lain yang mungkin dapat dilakukan adalah dengan mengembangkan teknik pelarutan bijih emas serta mengembangkan material baru adsorben, sebagai contoh menggunakan kitosan sebagai bahan dasar.

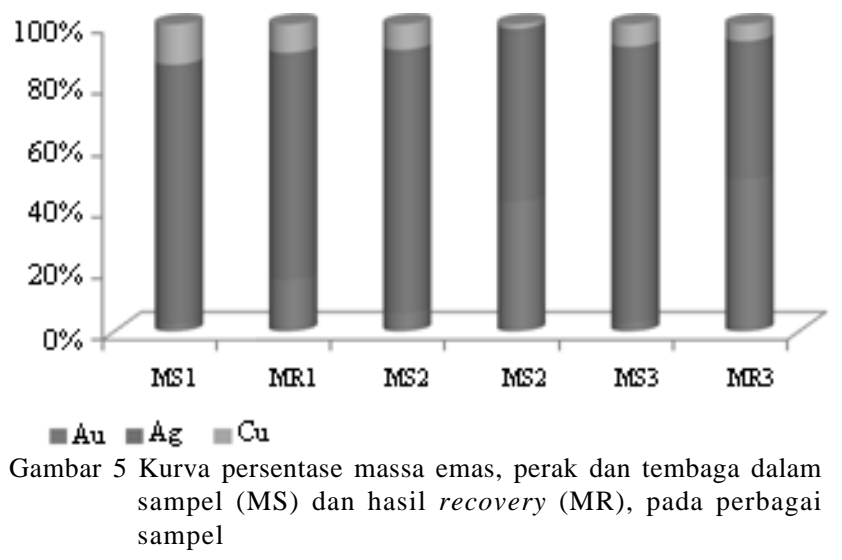




\section{SIMPULAN}

Karbon aktif dari tempurung kelapa dapat digunakan sebagai adsorben pada recovery emas yang berasal dari bijih emas berkadar rendah. Recovery emas maksimum diperoleh pada konsentrasi eluen ( $\left.\mathrm{SCN}^{-}\right) 1 \mathrm{M}$ dan panjang kolom $5 \mathrm{~cm}$ (berat karbon aktif 20 gram). Hasil uji recovery emas, perak dan tembaga pada sampel bijih emas yang mengandung 0,06 ppm emas, 2,14 ppm perak dan 0,88 ppm tembaga adalah $46,05 \% ; 11,85 \%$ dan $36,98 \%$.

Dari hasil penelitian diketahui bahwa pada proses adsorpsi recovery emas maksimum diperoleh pada $\mathrm{pH} 3$ dan pada proses desorpsi $\mathrm{pH}$ 5. Pada kondisi tersebut diperoleh recovery rata-rata emas sebesar 90,00\%, perak $7,28 \%$ dan tembaga $4,93 \%$, dengan menggunakan berbagai sampel bijih emas. Tingkat kemurnian emas maksimum mencapai 49,67\%, tergantung pada konsentrasi emas, perak dan tembaga yang terkandung dalam sampel bijih emas.

\section{UCAPANTERIMAKASIH}

Penelitian ini dibiayai melalui Penelitian Hibah Bersaing XIV tahun anggaran 2006 (Surat Perjanjian Pelaksanaan Penelitian No : 323/SP3/PP/DP2M/II/2006) dan
2007 (Surat Perjanjian Pelaksanaan Penelitian No : 017/SP2H/ PP/DP2M/III/2007).

\section{DAFTAR PUSTAKA}

Adam, M.D.Ed. 2005. Advances in Goid Processing, Mutis Liber Pty Ltd., Guildford, WA, Australia.

Adiwilaga, S. 1991. A study of gold adsorption from Cimanggu thiourea solution by coconut shell activated carbon, Teknologi Indonesia 14: 1-11.

Grosse, A.C., Dicinoski, G.W., Shaw, M.J. \& Haddad, P.R. 2003. Leaching and recovery of gold using ammoniacal thiosulfate leach liquors (a review), Hydrometallurgy 69: $1-21$.

Heinen, J.D., Peterson, G. \& Lindstrom, R.E. 1978. Processing Gold ores Using heap Leachsarbon Adsorption Methods, Bureau of Mines, U.S. Dept. of the Interior, Washington.

Jiang, T., Zhang, Y., Yang, Y. \& Huang, Z. 2001. Influence of copper minerals on cyanide leaching of gold, Journal of Central South University of Technology 8: 24-28.

Klein, C. \& Hurbult, C.S. 1985. Manual of Mineralogy, $20^{\text {th }}$ ed., John Wiley; Sons Inc., New York.

Marsden, J.O. \& House, C.L. 2006. The Chemistry of Gold Extraction, $2^{\text {nd }}$ ed., Society for Mining, Metallurgy, and Exploration, Colorado; USA. Inc.

Navarroa, P., Vargasa, C., Alonsob, M. \& Alguacilb, F.J. 2006. The adsorption of gold on activated carbon from thiosulfateammoniacal solutions, Gold Bulletin 36: 93-97.

Suzuki, M., Matsumoto, Z. \& Fukui, T. 1991. Activated carbon for recovery of gold, American Patent 5019162.

Wei, S., Li, Zh. \& Yaping, Zh. 2006. Preparation of microporous activated carbon from raw coconut, Chinese Journal Chemical Enginering 14: 266-269. 